\title{
BIBLIOGRAFIA
}

„Studia Wyborcze”, tom 28, 2019

DOI: https://doi.org/10.26485/SW/2019/28/7

Anna Frydrych-Depka*, Paweł Raźny**

\section{POLSKA BIBLIOGRAFIA WYBORCZO-REFERENDALNA ZA 2018 ROK}

Adamiec A., Kalendarz komisarza wyborczego, [w:] Konsekwencje rewolucji w prawie wyborczym, czyli jak postawić krzyżyk $i$ dlaczego $w$ kratce, red. W. Hermeliński, B. Tokaj, A. Godzwon, A. Adamiec, Warszawa 2018, s. 123-135.

Adamiec A., Komisarz wyborczy - jaki byt, jaki będzie?, [w:] Konsekwencje rewolucji w prawie wyborczym, czyli jak postawić krzyżyk $i$ dlaczego $w$ kratce, red. W. Hermeliński, B. Tokaj, A. Godzwon, A. Adamiec, Warszawa 2018, s. 111-122.

Adamiec A., Urzędnicy wyborczy, [w:] Konsekwencje rewolucji w prawie wyborczym, czyli jak postawić krzyżyk i dlaczego w kratce, red. W. Hermeliński, B. Tokaj, A. Godzwon, A. Adamiec, Warszawa 2018, s. 137-144.

Adamik-Szysiak M., Kampania wyborcza do Parlamentu Europejskiego w 2014 roku na lamach prasy ogólnopolskiej - studium przypadku ,Gazety Wyborczej” i „,Rzeczpospolitej”, „Środkowoeuropejskie Studia Polityczne” 2018, nr 1, s. 79-96.

Aktualne problemy prawa wyborczego. Tom. 2, red. E. Żelasko-Makowska, K. Mucha, B. Przywora, M. Wrzalik, Częstochowa 2018.

Amerykańskie wybory $w$ erze postprawdy, red. J. Misiuna, M. Molenda-Zdiech, S. Łubiarz, Warszawa 2018.

Arato K., Constructing the Reality: the Perception of the European Union in the 2018 Hungarian Electoral Campaign, „Yearbook of the Institute of East-Central Europe” 2018, vol. 16 (5), s. 39-60.

Augustyniak M., Bielecki L., Ruczkowski P., Wybory samorzadowe: komentarz, Warszawa 2018.

Augustyniak M., Wybory samorzadowe 2018: zagadnienia praktyczne $i$ schematy działań, Warszawa 2018.

Babiarz S., Wiącek M., Omówienie do uchwały NSA z dnia 11 grudnia 2017 r., II OPS 2/17, „Zeszyty Naukowe Sądownictwa Administracyjnego” 2018, nr 1, s. 128-131.

* Dr, adiunkt, Centrum Studiów Wyborczych Uniwersytetu Mikołaja Kopernika w Toruniu, aniafryd@umk.pl, ORCID: 0000-0002-3765-4046.

** Mgr, asystent, Centrum Studiów Wyborczych Uniwersytetu Mikołaja Kopernika w Toruniu, pawelrazny@umk.pl, ORCID: 0000-0003-2604-4602. 
Babula M., Electoral Rights and Intellectual Disability: Considerations de lege lata, „Polish Political Science Yearbook" 2018, vol. 47 (4), s. 642-651.

Bäcker R., Rak J., The Change of Russian Political Regime from the "White Revolution" to Presidential Election (2012-2018), „Przegląd Strategiczny” 2018, nr 11, s. 143-156.

Balicki R., Zmiana zasad tworzenia okreggów wyborczych w wyborach samorzadowych $w$ nowelizacji Kodeksu wyborczego z 2018 r., „Przegląd Prawa Konstytucyjnego” 2018, nr 4 (44), s. 57-69.

Banaszak B., Michalska J., Kodeks wyborczy: komentarz 3. wydanie, aktualizacja J. Michalska, Warszawa 2018.

Barabasz A., The Polish People's Republic in the context of elections to the European Parliament of the European Community (1979), „Rocznik Integracji Europejskiej” 2018, nr 12, s. $371-380$.

Bartnicki S., Czynniki reelekcji inkumbentów na stanowiskach gminnej egzekutywy w gminach miejskich i miejsko-wiejskich w 2014 roku, „Acta Politica Polonica” 2018, nr 1, s. 1-74.

Bartnicki S., Pożytki z miejsca na karcie wyborczej w konkurencyjnych wyborach bezpośrednich organu wykonawczego gmin rozgrywanych $w$ trybie open race, „Athenaeum. Polskie Studia Politologiczne" 2018, vol. 57, s. 78-102.

Bartnicki S., Szanse wyborcze wójtów ubiegających się o reelekcję $w$ wyborach $w 2014$ r., „Samorząd Terytorialny” 2018, nr 11, s. 79-92.

Bartnicki S., Uwarunkowania dominacji ubiegajacych się o reelekcję do organu wykonawczego gmin $w$ wyborach $w 2014 r$. w gminach niebędacych miastami na prawach powiatu, „Samorząd Terytorialny" 2018, nr 4, s. 21-35.

Bartnicki S., Uwarunkowania szans wyborczych ubiegajacych się o reelekcję wójtów i burmistrzów w wyborach w 2014 roku, „Annales UMCS. Sectio K Politologia”, vol. 25 (1), s. $133-156$.

Bezubik K., Wpływ orzeczeń Federalnego Trybunatu Konstytucyjnego na nowelizacje ustawy wyborczej do Bundestagu w 2013 roku, [w:] Ustrój państwa, myśl polityczno-prawna, wspótczesne systemy rządów. Prace ofiarowane profesorowi zw. nauk prawnych Adamowi Jamrozowi z okazji Jego Jubileuszu, red. S. Bożyk, A. Olechno, Białystok 2018, s. 309-316.

Biel W., Kolorado czy Ohio? Dylematy kampanijne demokratów w kontekście rezultatu wyborów w 2016 roku, [w:] Amerykańskie wybory w erze postprawdy. Aktorzy, strategie, konteksty, red. J. Misiuna, M. Molenda-Zdziech, S. Łubiarz, Warszawa 2018, s. 97-116.

Bitner M., Finansowanie kampanii wyborczej do organów jednostek samorządu terytorialnego, „e-Politikon” 2018, nr 26, s. 138-164.

Bitner M., Status prawny i gospodarka finansowa komitetów wyborczych $w$ wyborach do organów jednostek samorzadu terytorialnego, „Finanse Komunalne” 2018, nr 9, s. 19-33.

Block W., Voting: Rejoinder to Casey, McElroy, Ward, Pugsley, Konkin and Barnett, „Political Dialogues" 2018, nr 24, s. 23-38.

Błasiak P., Prawne aspekty głosowania elektronicznego jako alternatywnej procedury głosowania, [w:] Aktualne problemy prawa wyborczego. Tom 2, red. E. Żelasko-Makowska, K. Mucha, B. Przywora, M. Wrzalik, Częstochowa 2018, s. 65-76.

Bohár A., The 2017 regional elections in Slovakia in the aspect of the Party of the Hungarian Community (Magyar Közösség Pártja - Strana Mad’arskej Komunity), „Wrocławskie Studia Erazmiańskie" 2018, nr 12, s. 497-510.

Bojarski M., Pozakodeksowe przestępstwa $w$ dziedzinie wyborów, polityki i inicjatywy ustawodawczej, [w:] Szczególne dziedziny prawa karnego. Prawo karne wojskowe, skarbowe i pozakodeksowe, red. M. Bojarski, Warszawa 2018, s. 1015-1051.

Borówka A., Problematyka określania spójności pogladowej wyborców i komitetów wyborczych na przyktadzie algorytmu aplikacji „Latarnik Wyborczy 2015”, „e-Politikon” 2018, nr 26, s. 234-255. 
Borski M., Ewolucja mechanizmów stwarzania osobom niepelnosprawnym $i$ w podeszłym wieku możliwości petnego udziału w akcie wyborczym, [w:] Aktualne problemy prawa wyborczego. Tom 2, red. E. Żelasko-Makowska, K. Mucha, B. Przywora, M. Wrzalik, Częstochowa 2018, s. 77-87.

Bożyk S., System wyborczy a układ sit politycznych w parlamencie Nowej Zelandii, [w:] Dookoła Wojtek... Księga pamiątkowa poświęcona Doktorowi Arturowi Wojciechowi Preisnerowi, red. R. Balicki, M. Jabłoński, Wrocław 2018, s. 535-543.

Brabec D., Development and trends of the general referendum law proposals in the Czech Republic, ,Annales UMCS. Sectio K Politologia”, vol. 25 (2), s. 99-115.

Brodzińska-Mirowska B., Porażka $w$ dobie profesjonalizacji: o konieczności zmiany perspektywy w komunikowaniu politycznym, [w:] Anatomia porażki wyborczej, red. A. Pacześniak, Warszawa 2018, s. 39-63.

Buczkowski Ł., Uwagi w sprawie propozycji zmian Kodeksu wyborczego, „Przegląd Prawa Konstytucyjnego" 2018, nr 3, s. 103-130.

Bułajewski S., Zakaz głosowania radnego w sprawie dotyczacej jego interesu prawnego. Glosa do wyroku WSA z dnia 22 grudnia 2011 r., II SA/Bk 167/11, „Samorząd Terytorialny” 2018, nr 1-2, s. 165-171.

Butrym M., Młodzi wyborcy: wybory parlamentarne 2011 i 2015: badania studentów z Lublina i Olsztyna, Olsztyn 2018.

Butrym M., Preferencje milczacego elektoratu. Straty poparcia komitetów wyborczych w wyniku absencji wyborczej studentów w 2015 roku, „Athenaeum. Polskie Studia Politologiczne” 2018, vol. 57, s. 35-53.

Campbell J.L., Why did Donald Trump really get elected?, „Zarządzanie Publiczne” 2018, nr 46, s. 5-18.

Chmaj M., Zasada tajności głosowania w kodeksie wyborczym, Toruń 2018.

Chrobak P., Preferencje wyborcze mieszkańców okręgu wyborczego $n r 13$ w wyborach do Parlamentu Europejskiego $i$ w referendum akcesyjnym do Unii Europejskiej, „Przegląd Zachodni” 2018, nr 3, s. 275-290.

Chrobak P., Referendum akcesyjne oraz wybory do Parlamentu Europejskiego w Szczecinie na tle Pomorza Zachodniego i Ziemi Lubuskiej w latach 2003-2014. Preferencje wyborcze mieszkańców regionów zachodniopomorskiego i lubuskiego, Poznań 2018.

Chwedoruk R., Regionalne zróżnicowanie poparcia w wyborach parlamentarnych po $2004 r$ r dla socjaldemokracji w Polsce na tle innych państw Europy Srodkowej i Wschodniej, [w:] Geografia wyborcza Polski: interpretacje postaw $i$ zachowań obywateli, red. T. Koziełł, D. Szczepański, Rzeszów 2018, s. 195-220.

Chwedoruk R., Rydliński B., Porażka partii peryferii w drodze do centrum - analiza geografii wyborczej SLD, [w:] Anatomia porażki wyborczej, red. A. Pacześniak, Warszawa 2018, s. $195-219$.

Cichosz M., Tomczak Ł., Implementation of the Quota System in the Regional Assembly Elections: the Analysis of Electoral Results in the Context of Women's Epresentation on Electoral Lists, „Przegląd Politologiczny” 2018, nr 4, s. 25-37.

Ciechanowska J., Wybory do organów samorzadu lokalnego, [w:] Ustrój państwowy Republiki Estonii, red. S. Sagan, Rzeszów 2018, s. 98-99.

Clair James Grece i koncepcja ,głosowania przeciw”, oprac. D. Szawurski-Radetz, Warszawa 2018.

Complak K., Artykuł 41 Konstytucji Meksyku (brzmienie, objaśnienia, znaczenie), [w:] Dookoła Wojtek... Księga pamiątkowa poświęcona Doktorowi Arturowi Wojciechowi Preisnerowi, red. R. Balicki, M. Jabłoński, Wrocław 2018, s. 545-556. 
Cukier-Syguła M., Wplyw wybranych instytucji demokracji deliberatywnej. Od teoretycznych rozważań do praktycznych działań, [w:] Oblicza demokracji lokalnej. Wyzwania dla rozwoju miast, red. M. Obrębska, Sosnowiec 2018, s. 133-151.

Czapiewski T., Brytyjskie wybory do Izby Gmin w 2017 roku wobec procesu wyjścia Zjednoczonego Królestwa z Unii Europejskiej, „Studia Europejskie” 2018, nr 3, s. 51-74.

Czaplicki K.W. Dauter B., Jaworski S.J., Kisielewicz A., Rymarz F., Zbieranek J., Kodeks wyborczy. Komentarz, wyd. 2, aktualizacja J. Zbieranek, Warszawa 2018.

Czarny P., Kandydowanie sekretarzy $i$ skarbników gmin, powiatów oraz województw w wyborach na urząd wójta, burmistrza lub prezydenta miasta, „Zeszyty Prawnicze BAS” 2018, nr 2, s. 47-53.

Czech F., Conspiracy Theories Are Not Only for Election Losers. Anti-system Parties and Conspiratorial Distrust in Poland, „Polish Political Science Yearbook” 2018, vol. 47 (4), s. 663-675.

Czerw J., Ewolucja zasad wyboru wójta, [w:] Aktualne problemy prawa wyborczego. Tom 2, red. E. Żelasko-Makowska, K. Mucha, B. Przywora, M. Wrzalik, Częstochowa 2018, s. 89-98.

Cześnik M., Political activity of the citizens, [w:] Polish political system An introduction, ed. J. Szymanek, Warszawa 2018, s. 160-177.

Delong M., Stanowisko Konferencji Episkopatu Polski wobec wyborów parlamentarnych w 1991 roku, „Politeja” 2018, nr 53, s. 257-270.

Derevianko S., Derevianko O., Models of Local Referendum According to the Constitutions of Ukraine and Countries of Central and Eastern Europe: comparative-typological characteristics, [w:] Samorzad terytorialny w konstytucjach wybranych państw Europy Środkowo-Wschodniej. Zarys problematyki, red. I. Lasek-Surowiec, Chełm 2018, s. 87-101.

Dobrowolski M., Przyczyny porażki Sojuszu Lewicy Demokratycznej w wyborach parlamentarnych w 2015 r., „Społeczeństwo i Polityka. Pismo Edukacyjne” 2018, nr 1, s. 83-98.

Donaj Ł., Kusa N., "Non-campaign of a non-candidate" - Alexei Navalny in the 2018 presidential election in Russia, „Środkowoeuropejskie Studia Polityczne” 2018, nr 3, s. 21-34.

Drosik A., Early voting $w$ amerykańskich kampaniach prezydenckich, [w:] Amerykańskie wybory $w$ erze postprawdy. Aktorzy, strategie, konteksty, red. J. Misiuna, M. Molenda-Zdziech, S. Łubiarz, Warszawa 2018, s. 117-138.

Drzonek M., Flis J., Wołek A., Wybory lokalne, [w:] Atlas wyborczy Polski, red. M. Kowalski, P. Śleszyński, Warszawa 2018, s. 233-240.

Drzonek M., Pochwała bezpartyjności? Paradoksy zachowań elektoratów partyjnych $w$ wyborach prezydenta Szczecina, [w:] Geografia wyborcza Polski: interpretacje postaw i zachowań obywateli, red. T. Koziełło, D. Szczepański, Rzeszów 2018, s. 154-168.

Dudek D., Referendum - instrument czy iluzja władzy polskiego suwerena?, „Ruch Prawniczy, Ekonomiczny i Socjologiczny" 2018, vol. 80 (1), s. 169-185.

Dziemidok-Olszewska B., Zarzadzenie referendum przez Prezydenta w trybie art. 125 Konstytucji Rzeczypospolitej Polskiej: przypadek 2015 roku, [w:] Uwarunkowania demokracji bezpośredniej we wspótczesnej Europie, red. M. Musiał-Karg, A. Stelmach, Poznań 2018, s. 119-129.

Dziewulska A., Ostrowska A.M., „Glosuje.com.pl” $i$ „,MyCandidate.eu”, ,e-Politikon” 2018, nr 25 , s. 86-114.

Eska-Mikołajewska J., Parlament $w$ nowozelandzkim ustroju politycznym przed i po zmianie systemu wyborczego w 1993 roku, „Przegląd Sejmowy” 2018, nr 2, s. 9-34.

Firlus J.G., Fox N., Teoretyczna korelacja statusu mniejszości językowych a prawo do reprezentacji na szczeblu lokalnym i regionalnym - uwagi wokót województwa śląskiego, [w:] Geografia wyborcza Polski: interpretacje postaw i zachowań obywateli, red. T. Koziełło, D. Szczepański, Rzeszów 2018, s. 50-60. 
Flis J., Gendźwiłł, Stolicki K., Rywale włodarzy. Doświadczenia i szanse samorzadowych pretendentów, „e-Politikon” 2018, nr 26, s. 33-64.

Flis J., Stolicki D., Przechyly terytorialne - zróżnicowania wyborczej bazy samorządowych wlodarzy, [w:] Geografia wyborcza Polski: interpretacje postaw $i$ zachowań obywateli, red. T. Koziełło, D. Szczepański, Rzeszów 2018, s. 63-75.

Flis J., Wanatowicz M., Poetyka polityka - komitet jako komunikat w wyborach lokalnych, [w:] Komunikowanie lokalno-regionalne $w$ dobie spoleczeństwa medialnego. Tom 2, Aspekty polityczne, społeczne i technologiczne, red. M. Mazur, M. Kornacka-Grzonka, Katowice 2018, s. 64-80.

Frydrych-Depka A., Instytucja komisarza wyborczego i urzędników wyborczych po nowelizacji kodeksu wyborczego, „Studia Iuridica Toruniensia” 2018, t. 23, s. 55-72.

Frydrych-Depka A., Prawo do informacji o wyborach, „Studia Wyborcze” 2018, t. 25, s. 57-70.

Frydrych-Depka A., Rola sekretarza w organizacji wyborów, [w:] Vademecum sekretarza jednostki samorzadu terytorialnego, red. A. Grytner, Warszawa 2018, s. 471-509.

Furman W., Sprawozdawcy czy doradcy? Działania dziennikarzy gazet regionalnych „Nowiny” $i$ „, Glos Szczeciński” w parlamentarnej kampanii wyborczej w 2015 r., [w:] Geografia wyborcza Polski: interpretacje postaw i zachowań obywateli, red. T. Koziełło, D. Szczepański, Rzeszów 2018, s. 295-313.

Gagatek W., Dylematy tworzenia nawigatorów wyborczych na przykładzie projektów „EU Profiler” $i$,,euandi”, ,e-Politikon” 2018, nr 25, s. 148-182.

Gagatek W., Referendum brytyjskie w 2016 r. z perspektywy teorii formowania sie preferencji państw czlonkowskich UE, „Studia Europejskie” 2018, nr 1, s. 69-88.

Gajda A., Głosowanie korespondencyjne w Polsce, [w:] Aktualne problemy prawa Polski i Ukrainy, red. A. Szmyt, J. Boszycki, J. Stelina, W. Mikołajowicz Iwanow, Gdańsk 2018, s. $63-72$.

Galicki J., Wybory jako metoda kształtowania składu organów stanowiacych samorzadu terytorialnego, [w:] Charakterystyka prawna mandatu radnego, Warszawa 2018, s. 49-125.

Ganowicz E., Inkluzywna funkcja bezpośrednich wyborów wójtów, burmistrzów i prezydentów miast, Opole 2018.

Gąsior T., Gąsior G., Organizacja wyborów samorzadowych - wybrane zagadnienia, Warszawa 2018.

Gierach E., W sprawie momentu wygaśnięcia mandatu posła, który w trakcie kadencji zostat mianowany na stanowisko ambasadora, „Przegląd Sejmowy” 2018, nr 5 (148), s. 139-144.

Gill N., Postępowanie w trybie wyborczym, „Przegląd Prawa Konstytucyjnego” 2018, nr 4, s. $105-119$.

Giżyńska M., Kilka uwag dotyczacych wspótczesnych wyborów i demokracji przedstawicielskiej, [w:] Dookoła Wojtek... Księga pamiątkowa poświęcona Doktorowi Arturowi Wojciechowi Preisnerowi, red. R. Balicki, M. Jabłoński, Wrocław 2018, s. 385-392.

Glinka K., Na styku marketingu wyborczego i miejskiego? W poszukiwaniu predyktora pozycji systemowej prezydentów największych polskich miast, „Annales UMCS. Sectio K Politologia”, vol. 25 (1), s. 157-174.

Gmaj K., Iglicka K., Imigranci wyborcy w Polsce - będac „, tuż za rogiem”, „Myśl Ekonomiczna i Polityczna" 2018, nr 3, s. 228-257.

Goban-Klas T., Superman autopromocji - od dewelopera do fotela prezydenta USA, [w:] Amerykańskie wybory w erze postprawdy. Aktorzy, strategie, konteksty, red. J. Misiuna, M. Molenda-Zdziech, S. Łubiarz, Warszawa 2018, s. 293-300.

Godzwon A., 2014-2015-2017 zmiany w prawie wyborczym, [w:] Konsekwencje rewolucji $w$ prawie wyborczym, czyli jak postawić krzyżyk i dlaczego w kratce, red. W. Hermeliński, B. Tokaj, A. Godzwon, A. Adamiec,Warszawa 2018, s. 47-68. 
Godzwon A., Głosowanie korespondencyjne - już nie dla każdego, [w:] Konsekwencje rewolucji w prawie wyborczym, czyli jak postawić krzyżyk i dlaczego w kratce, red. W. Hermeliński, B. Tokaj, A. Godzwon, A. Adamiec,Warszawa 2018, s. 145-159.

Godzwon A., Nie ufaj sprawdzaj, czyli rzecz o mężach zaufania, [w:] Konsekwencje rewolucji w prawie wyborczym, czyli jak postawić krzyżyk i dlaczego w kratce, red. W. Hermeliński, B. Tokaj, A. Godzwon, A. Adamiec,Warszawa 2018, s. 161-177.

Godzwon A., Sfatszowane wybory samorzadowe 2014? Fakty i mity, [w:] Konsekwencje rewolucji w prawie wyborczym, czyli jak postawić krzyży i dlaczego w kratce, red. W. Hermeliński, B. Tokaj, A. Godzwon, A. Adamiec,Warszawa 2018, s. 1-45.

Godzwon A., Transmisja z lokali wyborczych albo przepraszamy za usterki, [w:] Konsekwencje rewolucji $w$ prawie wyborczym, czyli jak postawić krzyżyk $i$ dlaczego $w$ kratce, red. W. Hermeliński, B. Tokaj, A. Godzwon, A. Adamiec,Warszawa 2018, s. 179-191.

Górka M., Cybertools of Political Competition and the 2016 American Presidential Campaign, „Polish Political Science Yearbook” 2018, vol. 47 (4), s. 628-641.

Grabowska S., The institution of a national referendum in Poland after 1945, „Przegląd Prawa Konstytucyjnego" 2018, nr 6, s. 199-218.

Grabowski R., Fakultatywne referendum zatwierdzajace w procesie zmiany konstytucji w państwach europejskich. Forma partycypacji obywatelskiej czy instytucja fasadowa?, [w:] Dookoła Wojtek... Księga pamiątkowa poświęcona Doktorowi Arturowi Wojciechowi Preisnerowi, red. R. Balicki, M. Jabłoński, Wrocław 2018, s. 601-608.

Grabowski W., Determinanty przestrzennego zróżnicowania wyników głosowania $w$ wyborach parlamentarnych z 2015 roku, „Studia Socjologiczne” 2018, nr 228, s. 35-64.

Gronau A., Prezydencka kampania wyborcza w 2015 roku na łamach wybranych tygodników opinii, Gdańsk 2018.

Grzybowski M., Grzybowski M., Ochrona dóbr osobistych i prywatności uczestników kampanii wyborczej w Stanach Zjednoczonych Ameryki i w Szwecji a prowadzenie blogów wyborczych [w:] Dookoła Wojtek... Księga pamiatkowa poświęcona Doktorowi Arturowi Wojciechowi Preisnerowi, red. R. Balicki, M. Jabłoński, Wrocław 2018, s. 609-620.

Gulińska E., Prawo mieszkańców do kierowania sprawami publicznymi w samorządzie gminnym, „Civitas et Lex” 2018, nr 3, s. 17-30.

Gurdek M., Informal rules of competition for power applied by self-government employees in local election, „Przegląd Prawa Publicznego” 2018, nr 7-8, s. 54-62.

Gwóźdź T., Ordynacja większościowa czy proporcjonalna?: analiza wyników wyborów do rad gmin niebędacych miastami na prawach powiatu oraz gmin będacych miastami na prawach powiatu, [w:] Aktualne problemy prawa wyborczego. Tom 2, red. E. Żelasko-Makowska, K. Mucha, B. Przywora, M. Wrzalik, Częstochowa 2018, s. 99 -110.

Hayn P., Wybory samorządowe do Rady Miasta Dębica w 2010 i 2014 r. - analiza porównawcza, [w:] Geografia wyborcza Polski: interpretacje postaw i zachowań obywateli, red. T. Koziełło, D. Szczepański, Rzeszów 2018, s. 265-276.

Hermeliński W., Aktualne problemy prawa wyborczego przed wyborami do jednostek samorządu terytorialnego, „Przegląd Prawa Konstytucyjnego” 2018, nr 4, s. 11-18.

Hermeliński W., Organy wyborcze-modyfikacja systemu sędziowskiego w kierunku politycznego, [w:] Konsekwencje rewolucji w prawie wyborczym, czyli jak postawić krzyży $i$ dlaczego w kratce, red. W. Hermeliński, B. Tokaj, A. Godzwon, A. Adamiec, Warszawa 2018, s. 85-99.

Hermeliński W., Zmiana znaku „X” i odstapienie od zasady świętości kratki, [w:] Konsekwencje rewolucji w prawie wyborczym, czyli jak postawić krzyży $i$ dlaczego $w$ kratce, red. W. Hermeliński, B. Tokaj, A. Godzwon, A. Adamiec, Warszawa 2018, s. 101-109. 
Ignasiak A., Zachowania wyborcze elektoratu wybranych miast średniej wielkości $w$ Polsce w latach 2001-2015, [w:] Geografia wyborcza Polski: interpretacje postaw i zachowań obywateli, red. T. Koziełło, D. Szczepański, Rzeszów 2018, s. 97-112.

Ilski Z., Wybory do Sejmu Ustawodawczego w 1919 roku. Rysy kampanii, „Przegląd Sejmowy” 2018, nr 6, s. 27-56.

Jakubowska U., O naturze preferencji politycznych: perspektywa psychologiczna, Warszawa: 2018.

Jankowski P., Osobliwości systemu wyborczego USA na przykładzie wyborów prezydenckich, [w:] Amerykańskie wybory w erze postprawdy. Aktorzy, strategie, konteksty, red. J. Misiuna, M. Molenda-Zdziech, S. Łubiarz, Warszawa 2018, s. 139-156.

Jaskiernia J., Wpływ standardów demokratycznych Rady Europy na ksztalt samorzadowego prawa wyborczego w Polsce, [w:] Aktualne problemy prawa wyborczego. Tom 2, red. E. Żelasko-Makowska, K. Mucha, B. Przywora, M. Wrzalik, Częstochowa 2018, s. 111-131.

Jednaka W., Nowo powstałe partie małe $w$ Polsce a wybory 2010-2011. Progi rozwoju partii, „Wrocławskie Studia Politologiczne” 2018, nr 25, s. 87-100.

Jirásková V., Referendum v České republice: diskuse pokračují, [w:] Potentia non est nisi da bonum: ksiegga jubileuszowa dedykowana profesorowi Zbigniewowi Witkowskiemu, red. A. Bień-Kacała, A. Kustra-Rogatka, M. Serowaniec, Toruń 2018, s. 445-457.

Jomma F., Europejska i międzynarodowa reakcja na referendum niepodległościowe $w$ irackim Kurdystanie, „Przegląd Europejski” 2018, nr 2, s. 201-227.

Jureczko J., Referenda odwolawcze $w$ sprawie odwotania organu wykonawczego $w$ województwie dolnośląskim w latach 2006-2016: partycypacja obywateli czy polityczna rozgrywka?, [w:] Uwarunkowania demokracji bezpośredniej we wspótczesnej Europie, red. M. Musiał-Karg, A. Stelmach, Poznań 2018, s. 179-189.

Kacperski K., Koncepcje systemu wyborczego do Sejmu na ziemiach Królestwa Polskiego w latach 1917-1918, Warszawa 2018.

Kacperski K., Prawo wyborcze do Sejmu Ustawodawczego, „Przegląd Sejmowy” 2018, nr 6, s. 7-84.

Kacperski K., Stulecie praw wyborczych kobiet w Polsce, „Infos” 2018, nr 12, ss. 4.

Kaczmarek-Śliwińska M., Aspekty public relations w strategiach wyborczych kandydatów na urzad prezydenta USA w 2016 roku, [w:] Amerykańskie wybory w erze postprawdy. Aktorzy, strategie, konteksty, red. J. Misiuna, M. Molenda-Zdziech, S. Łubiarz, Warszawa 2018, s. $277-292$.

Kamińska M., Krakowiak-Drzewiecka M., Kristof A., Ustawa o bezpośrednim wyborze wójta, burmistrza, prezydenta miasta - założenia a rzeczywistość, „Przegląd Prawa Publicznego” 2018, nr 6, s. 71-95.

Kasprowicz D., Hess A., Słupek L., "Barometr Wyborczy 2014" w procesie pozyskiwania danych na temat lokalnego komunikowania politycznego, ,e-Politikon” 2018, nr 25, s. 54-85.

Kasprzyk W.M., Obraz powyborczy (w wybranych miastach) w województwie dolnoślaskim i podkarpackim po wprowadzeniu systemu jednomandatowych okręgów wyborczych, [w:] Geografia wyborcza Polski: interpretacje postaw i zachowań obywateli, red. T. Koziełł, D. Szczepański, Rzeszów 2018, s. 277-292.

Kietliński M., Telewizyjne debaty prezydenckie jako decydujace $w$ kampaniach wyborczych: Kennedy vs. Nixon oraz Trump vs. Clinton, [w:] Amerykańskie wybory w erze postprawdy. Aktorzy, strategie, konteksty, red. J. Misiuna, M. Molenda-Zdziech, S. Łubiarz, Warszawa 2018, s. 223-244.

Kleinowski M., The Impact of Brexit and the New Legal Framework for European Statistics in Demography on the Voting Power of Poland in the Council of the European Union, „Athenaeum. Polish Political Science Studies” 2018, vol. 59, s. 141-157. 
Klepka R. Medialna walka o dobra zmianę: obraz wyborów parlamentarnych w 2015 roku w wybranych mediach, Kraków 2018.

Klepka R., Kandydaci drugiego planu w prezydenckiej kampanii wyborczej w 2015 roku: ile uwagi poświęcity im Wiadomości TVP?, „Roczniki Nauk Społecznych” 2018, vol. 16 (2), s. $123-142$.

Kłos M., Instytucja referendum w Zjednoczonym Królestwie Wielkiej Brytanii i Irlandii Pótnocnej na przykladzie referendum z $2016 \mathrm{r}$. w sprawie dalszego czlonkostwa $w$ Unii Europejskiej, [w:] Aktualne problemy prawa wyborczego. Tom 2, red. E. Żelasko-Makowska, K. Mucha, B. Przywora, M. Wrzalik, Częstochowa 2018, s. 133-143.

Kochanecki A., Dażenia niepodlegtościowe Katalonii w XX $i$ XXI w. w kontekście referendum niepodległościowego z 1 października 2017 r., „Przegląd Geopolityczny” 2018, t. 23, s. 144-157.

Konsekwencje rewolucji w prawie wyborczym, czyli jak postawić krzyżyk $i$ dlaczego $w$ kratce, red. W. Hermeliński, B. Tokaj, A. Godzwon, A. Adamiec, Warszawa 2018.

Kopańska A., Kula G., Siwińska-Gorzelak J., Bukowska G., Młochowska M., Reelekcje wójtów, burmistrzów i prezydentów miast a poziom autonomii fiskalnej, [w:] Autonomia fiskalna i jej wptyw na działania samorządów, Warszawa 2018, s. 189-210.

Kopeć A., Przymus głosowania: rozważania w kontekście frekwencji wyborczej i legitymizacji władzy, [w:] Aktualne problemy prawa wyborczego. Tom 2, red. E. Żelasko-Makowska, K. Mucha, B. Przywora, M. Wrzalik, Częstochowa 2018, s. 145-153.

Koszel B., Wielcy przegrani. Socjaldemokratyczni kandydaci na kanclerza Niemiec w latach 2009-2017, „Przegląd Zachodni”, nr 2, s. 39-60.

Kościński P., Jak sfatszować wybory, Warszawa 2018.

Kowalska F., Human Smart Cities : partycypacja obywatelska w polskich miastach trzeciej generacji: rola władz lokalnych, [w:] Uwarunkowania demokracji bezpośredniej we wspótczesnej Europie, red. M. Musiał-Karg, A. Stelmach, Poznań 2018, s. 169-177.

Kowalski M., Co uksztaltowało regionalne zróżnicowania zachowań wyborczych?, [w:] Polskie etosy regionalne $i$ ich znaczenie $z$ perspektywy ogólnonarodowej, red. J. Szomburg, M. Wandałowski, Gdańsk: 2018, s. 59-65.

Kowalski P., Czas trwania kampanii wyborczych w świetle prawa, „Studia Wyborcze” 2018, t. 25, s. $71-84$.

Koziełło T., Województwa o najwyższym poparciu społecznym Ligi Polskich Rodzin w wyborach parlamentarnych, europejskich i samorzadowych (2001-2007), [w:] Geografia wyborcza Polski: interpretacje postaw i zachowań obywateli, red. T. Koziełło, D. Szczepański, Rzeszów 2018, s. 131-153.

Kozłowski K., Obniżenie cenzusu wieku wykonywania czynnego prawa wyborczego: kwestie konstytucyjnoprawne, [w:] Aktualne problemy prawa wyborczego. Tom 2, red. E. Żelasko-Makowska, K. Mucha, B. Przywora, M. Wrzalik, Częstochowa 2018, s. 155-174.

Kożdoń-Dębecka M., Internet $w$ prezydenckich kampaniach wyborczych $w$ USA $w$ latach 2000-2012, Warszawa 2018.

Kręcisz W., Glosa do postanowienia NSA z dnia 21 maja 2018 r., II OZ 584/18, „Zeszyty Naukowe Sądownictwa Administracyjnego" 2018, nr 4, s. 171-178.

Kruszyńska P., Rywalizacja w ramach listy wyborczej jako konsekwencja systemu list pótotwartych w wyborach do Sеjmu RP, „Wrocławskie Studia Politologiczne” 2018, nr 24, s. $18-32$.

Kryszeń G., Konstytucyjna regulacja podstawowych zasad prawa wyborczego, „Gdańskie Studia Prawnicze" 2018, t. XL, s. 225-236.

Kubiak P., Wybory do Bundestagu z 24 września 2017 roku i ich następstwa, „Przegląd Zachodni" 2018, nr 2, s. 7-38. 
Kulas B., Wendt J.A., Wybory samorzadowe do sejmików wojewódzkich w Polsce: analiza wyników i preferencje elektoratu, regiony stabilne i labilne w latach 2002-2014, Pelplin 2018.

Kuleszewicz A., Electoral System of the Republic of Belarus after 25 Years of Independence, „Polish Political Science Yearbook” 2018, vol. 47 (4), s. 618-627.

Kużelewska E., E-voting $w$ wyborach parlamentarnych $w$ Belgii, „Przegląd Europejski” 2018, nr 2, s. 143-157.

Kużelewska E., Referendum ogólnokrajowe w Stowacji - nieudany eksperyment, „Acta Politica Polonica" 2018, nr 1, s. 51-59.

Lesiewicz E., Referenda niepodległościowe w Katalonii, [w:] Uwarunkowania demokracji bezpośredniej we wspótczesnej Europie, red. M. Musiał-Karg, A. Stelmach, Poznań 2018, s. 41-52.

Leszczyńska K., Udziat obywateli w wyborach i referendach w Polsce po 1989 roku, „Eastern Review" 2018, t. 7, s. 49-71.

Leśniczak R., Reklama wyborcza $w$ regionalnej prasie łódzkiej w perspektywie kampanii parlamentarnej 2015 r., [w:] Komunikowanie lokalno-regionalne $w$ dobie spoleczeństwa medialnego. Tom 2, Aspekty polityczne, społeczne i technologiczne, red. M. Mazur, M. Kornacka-Grzonka, Katowice 2018, s. 95 -109.

Lis-Staranowicz D., Kobiece oblicze wyborów parlamentarnych w Polsce. Pomiędzy przeszłościq a teraźniejszościa, „Studia Wyborcze” 2018, t. 25, s. 31-44.

Lorenc K., Dobór i konstrukacja twierdzeń kwestionariusza w nawigatorach wyborczych (Voting Advice Applications): od problemów metodologicznych po ideologię, „e-Politikon 2018, nr 25, s. 183-202.

Ludwikowski R., Demokracja elektorska i populistyczna z perspektywy wyboru D. Trumpa na Prezydenta USA, „Państwo i Prawo” 2018, nr 1, s. 40-50.

Łubiarz S., Molęda-Zdziech M., Mediatyzacja kampanii prezydenckiej w Stanach Zjednoczonych - przeglad metod i technik, [w:] Amerykańskie wybory w erze postprawdy. Aktorzy, strategie, konteksty, red. J. Misiuna, M. Molenda-Zdziech, S. Łubiarz, Warszawa 2018, s. $197-222$.

Łukaszewski M., Arengo, obywatelska inicjatywa ustawodawcza, Instancja Arengo i referendum: formy demokracji bezpośredniej w San Marino na tle rozwiazań konstytucyjnych Włoch, [w:] Uwarunkowania demokracji bezpośredniej we współczesnej Europie, red. M. Musiał-Karg, A. Stelmach, Poznań 2018, s. 21-39.

Maciejewska-Mieszkowska K., Między relacja a informacją. Kampania wyborcza do Parlamentu Europejskiego w Telewizji Polskiej SA w 2014 r., „Roczniki Nauk Społecznych” 2018, vol. 16 (1), s. 107-122.

Madras T., Geografia wyborcza województwa podlaskiego, [w:] Geografia wyborcza Polski: interpretacje postaw i zachowań obywateli, red. T. Koziełło, D. Szczepański, Rzeszów 2018, s. 249-264.

Maj D., Ewolucja demokracji bezpośredniej na Litwie, Lotwie i w Estonii po 1991 roku: perspektywy rozwoju i bariery stosowania, [w:] Uwarunkowania demokracji bezpośredniej we wspótczesnej Europie, red. M. Musiał-Karg, A. Stelmach, Poznań 2018, s. 79-90.

Majcherkiewicz T., Wybory regionalne jako wybory drugorzędne a perspektywa rzadzenia wielopoziomowego, „Przegląd Politologiczny” 2018, nr 1, s. 171-190.

Marczewska-Rytko M., Demokracja bezpośrednia w Europie Środkowej i Wschodniej po 1989 roku: stan prawny i praktyka, [w:] Uwarunkowania demokracji bezpośredniej we wspótczesnej Europie, red. M. Musiał-Karg, A. Stelmach, Poznań 2018, s. 53-63.

Marszałek-Kawa J., Reflections on the Proposal to Introduce a Term Limit for Elected Officials Effects and Implications, „Polish Political Science Yearbook” 2018, vol. 47 (4), s. 752-761. 
Marzęcki R., Zróżnicowanie światopoglądowe a zachowania wyborcze młodych Polaków w 2015 r., [w:] Geografia wyborcza Polski: interpretacje postaw i zachowań obywateli, red. T. Koziełło, D. Szczepański, Rzeszów 2018, s. 76-96.

Matuszewski P., Walecka K., (Nie)świadome decyzje polityczne polskich użytkowników ,euandi"? Analiza wyników nawigatora wyborczego do Parlamentu Europejskiego w 2014 roku, „e-Politikon” 2018, nr 25, s. 242-273.

Matyja M., Demokracja bezpośrednia versus integracja mniejszości muzułmańskiej w Szwajcarii, ,Zoon Politikon” 2018, nr 9, s. 49-72.

Matynia T., Zmiany w obszarze zachowań wyborczych a powstanie i funkcjonowanie nawigatorów wyborczych, „e-Politikon” 2018, nr 25, s. 223-241.

Mazurkiewicz B., ,,Wieczni wójtowie”-zjawisko wielokadencyjności w gminach wiejskich. Analiza wyników wyborów w latach 2002-2014, „Acta Politica Polonica” 2018, nr 1, s. 75-87.

Mażewski L., Wybory i odwoływanie organów wykonawczych jednostek samorzadu terytorialnego de lege lata i de lege ferenda, [w:] Trzon państwa: wybory $i$ odwoływanie organów wykonawczych samorządu terytorialnego, powolywanie i odwolywanie Rady Ministrów, wybór Prezydenta RP oraz powolywania i odwolywania wojewody jako przedstawiciela Rady Ministrów w województwie pod rządami Konstytucji RP z 2 kwietnia 1997 r., Sopot 2018, s. 123-135.

Mażewski L., Wybory i odwoływanie wójta/burmistrza/prezydenta miasta jako monokratycznego organu wykonawczego gminy i miasta na prawach powiatu, [w:] Trzon państwa: wybory i odwoływanie organów wykonawczych samorzadu terytorialnego, powolywanie i odwolywanie Rady Ministrów, wybór Prezydenta RP oraz powoływania i odwoływania wojewody jako przedstawiciela Rady Ministrów w województwie pod rzadami Konstytucji RP z 2 kwietnia 1997 r., Sopot 2018, s. 43-55.

Mażewski L., Wybór Prezydenta RP, [w:] Trzon państwa: wybory i odwotywanie organów wykonawczych samorządu terytorialnego, powolywanie i odwotywanie Rady Ministrów, wybór Prezydenta RP oraz powoływania i odwotywania wojewody jako przedstawiciela Rady Ministrów w województwie pod rządami Konstytucji RP z 2 kwietnia 1997 r., Sopot 2018, s. 101-113.

Michalak B., Elections and electoral system, [w:] Polish political system An introduction, ed. J. Szymanek. Warszawa 2018, s. 113-133.

Michalak B., Zmiana przepisów Kodeksu wyborczego przed wyborami samorządowymi 2018, „Athenaeum. Polskie Studia Politologiczne” 2018, vol. 58, s. 75-99.

Michałkiewicz-Kądziela E., Milczarek E., Uwagi na temat wybranych aspektów nowelizacji Kodeksu wyborczego ustawa z dnia 11 stycznia 2018 roku o zmianie niektórych ustaw $w$ celu zwiększenia udziatu obywateli w procesie wybierania, funkcjonowania $i$ kontrolowania niektórych organów publicznych, [w:] Państwo i jego instytucje: konstytucja - sqdownictwo - samorząd terytorialny, red. R. Balicki, M. Jabłoński, Wrocław 2018, s. 243-257.

Misiaszek M., Misiek K., Historia i ewolucja gtosowania korespondencyjnego, [w:] Aktualne problemy prawa wyborczego. Tom 2, red. E. Żelasko-Makowska, K. Mucha, B. Przywora, M. Wrzalik, Częstochowa 2018, s. 175-183.

Misiuna J., Donald Trump i pieniadze w prezydenckiej kampanii wyborczej 2016 roku, [w:] Amerykańskie wybory w erze postprawdy. Aktorzy, strategie, konteksty, red. J. Misiuna, M. Molenda-Zdziech, S. Łubiarz, Warszawa 2018, s. 181-195.

Misiuna J., Molenda-Zdziech M., Łubiarz S., Amerykańskie wybory w erze postprawdy, [w:] Amerykańskie wybory $w$ erze postprawdy. Aktorzy, strategie, konteksty, red. J. Misiuna, M. Molenda-Zdziech, S. Łubiarz, Warszawa 2018, s. 9-17.

Modrzejewska E., Między świadomym glosowaniem a świadomym kandydowaniem, „e-Politikon" 2018, nr 25, s. 115-147. 
Modrzejewska-Leśniewska J., Afganistan w kampanii prezydenckiej $i$ w pierwszych miesiacach urzędowania prezydenta Donalda Trumpa, [w:] Amerykańskie wybory w erze postprawdy. Aktorzy, strategie, konteksty, red. J. Misiuna, M. Molenda-Zdziech, S. Łubiarz, Warszawa 2018, s. 71-95.

Mojski W., Nowelizacja Kodeksu wyborczego w 2018 r.w zakresie kampanii wyborczej i agitacji wyborczej, „Przegląd Prawa Konstytucyjnego” 2018, nr 4, s. 87-103.

Molska K., Brak poczucia sprawczości - wybory do parlamentu Europejskiego na tle wyborów samorząowych. Przykład województwa zachodniopomorskiego, „Acta Politica Polonica” 2018, nr 1, s. 65-74.

Mucha K., Wrzalik M., Pozbawienie czy ograniczenie czynnego prawa wyborczego?: wybrane problemy, [w:] Aktualne problemy prawa wyborczego. Tom 2, red. E. Żelasko-Makowska, K. Mucha, B. Przywora, M. Wrzalik, Częstochowa 2018, s. 195-207.

Musiał-Karg M., Analiza doświadczeń związanych z wykorzystaniem głosowania internetowego (i-voting) w wybranych państwach, „Zeszyty Prawnicze BAS” 2018, nr 1, s. 46-68.

Musiał-Karg M., Demokracja bezpośrednia w praktyce politycznej Macedonii, [w:] Uwarunkowania demokracji bezpośredniej we wspótczesnej Europie, red. M. Musiał-Karg, A. Stelmach, Poznań 2018, s. 109-118.

Musiał-Karg M., Referendum - instytucja wpływania na przyszłość zjednoczonej Europy. Brexit a ksztalt Unii Europejskiej, [w:] Integracja europejska. Polska perspektywa, red. Z. Czachór, T.G. Grosse, W. Paruch, Warszawa 2018, s. 541-561.

Musiał-Karg M., Duda K., Wprowadzenie praw wyborczych dla kobiet jako przyktad dysfunkcjonalności demokracji bezpośredniej w Szwajcarii, [w:] Uwarunkowania demokracji bezpośredniej we współczesnej Europie, red. M. Musiał-Karg, A. Stelmach, Poznań 2018, s. 9-20.

Niżnik-Mucha A., Wybrane zmiany kodeksu wyborczego $w$ świetle konstytucyjnych zasad prawa wyborczego, „Casus” 2018, nr 91 s. 11-15.

Niżyńska A., Czy porażka polityczna ma płeć?, [w:] Anatomia porażki wyborczej, red. A. Pacześniak, Warszawa 2018, s. 111-127.

Orłowski Ł., Głosowanie przez petnomocnika jako gwarancja korzystania z czynnego prawa wyborczego przez osoby starsze i niepetnosprawne, „Studenckie Prace Prawnicze, Administratywistyczne i Ekonomiczne" 2018, t. 26, s. 107-123.

Orłowski W., Electoral Law to the Constituent Sejm from the 100 Years' Perspective of its Adoption, „Przegląd Prawa Konstytucyjnego” 2018, nr 6, s. 89-104.

Ostapiuk A., Mroczka K., Protest wyborczy jako środek ochrony prawnej w yborach samorzqdowych - analiza instytucjonalno-prawna, ,e-Politikon” 2018, nr 26, s. 80-137.

Peck A., Religia $w$ amerykańskich wyborach prezydenckich, Warszawa 2018.

Peszyński W., Prezydencki i parlamentarny - style kampanii wyborczej, „Roczniki Nauk Społecznych" 2018, vol. 16 (2), s. 143-162.

Piasecki A., Ptak A., Sto lat władzy lokalnej na polskiej wsi 1918-2018, Warszawa 2018.

Pierzgalski M., Odkrywanie fatszerstw wyborczych a „prawo” Benforda, „Środkowoeuropejskie Studia Polityczne" 2018, nr 1, s. 121-139.

Pietrzyk B., Make America great again! Twitter w rękach Donalda Trumpa - narracje i konteksty, [w:] Amerykańskie wybory w erze postprawdy. Aktorzy, strategie, konteksty, red. J. Misiuna, M. Molenda-Zdziech, S. Łubiarz, Warszawa 2018, s. 261-276.

Pisz M., Konstytucyjne i ustawowe uwarunkowania instytucji e-votingu w polskim porzadku prawnym, „Przegląd Legislacyjny” 2018, nr 3, s. 45-58.

Plecka D., Rutkowska P., Social Security of Citizens in the Manifesto of the Christian Democratic Union and the Christian Social Union for the 2017 Parliamentary Election in Germany, „Przegląd Politologiczny” 2018, nr 3, s. 109-118.

Pogłódek A., Instytucja referendum we współczesnym Kirgistanie: studium prawno-polityczne, Warszawa 2018. 
Pokładecki J., Partycypacja a lokalny system polityczny, „Eastern Review” 2018, t. 7, s. 105-123.

Porębski L., Czy system demokratyczny potrzebuje partycypacji? O roli demokracji bezpośredniej - w Konstytucji RP $i$ w ksztaltowaniu teorii demokracji, „Horyzonty Polityki” 2018, vol. 9 (26), s. 63-76.

Potulski J., Zwycięstwo wyborcze Donalda Trumpa jako przyktad drugiej fali kontrmobilizacji, [w:] Amerykańskie wybory w erze postprawdy. Aktorzy, strategie, konteksty, red. J. Misiuna, M. Molenda-Zdziech, S. Łubiarz, Warszawa 2018, s. 157-180.

Przybysz Ł., Efekt America first: kampania Every Second Counts jako echo polityki Donalda Trumpa, [w:] Amerykańskie wybory w erze postprawdy. Aktorzy, strategie, konteksty, red. J. Misiuna, M. Molenda-Zdziech, S. Łubiarz, Warszawa 2018, s. 245-260.

Przywora B., Gtosowanie korespondencyjne w Polsce po nowelizacji kodeksu wyborczego w 2018 r.: kilka refleksji, [w:] Aktualne problemy prawa wyborczego. Tom 2, red. E. Żelasko-Makowska, K. Mucha, B. Przywora, M. Wrzalik, Częstochowa 2018, s. 209-221

Pyrzyńska A., Społeczni obserwatorzy wyborów w polskim prawie wyborczym, „Studia Wyborcze" 2018, t. 26, s. 7-24.

Pyrzyńska A., Supervision of the State Electoral Commission over electoral committees during the election campaign, „Studia z Zakresu Nauk Prawnoustrojowych. Miscellanea” 2018, t. 8 (2), s. $173-190$.

Pytel A., Problematyka treści znowelizowanego art. 156 i art. $191 \mathrm{~g}$ Kodeksu wyborczego, „Samorząd Terytorialny 2018, nr 10, s. 56-65.

Rachwał M., The relationship between position on an electoral list and chances of winning a seat in a representative body; experiences from the 2015 Sejm election in Poland, „Przegląd Politologiczny" 2018, nr 3, s. 135-144.

Rakowska-Trela A., 100 years of women suffrage in Poland. From the fight for political rights to gender quotas, „Przegląd Prawa Konstytucyjnego” 2018, nr 6, s. 261-272.

Rakowska-Trela A., Current Amendments to Polish Electoral Law in the Light of European Standards, „Polish Political Science Yearbook” 2018, vol. 47 (3), s. 457-466.

Rakowska-Trela A., Nowelizacja samorzadowego prawa wyborczego z 2018 r., „Przegląd Prawa Konstytucyjnego" 2018, nr 4, s. 19-35.

Rakowska-Trela A., Składowski K., Kodeks wyborczy: komentarz do zmian 2018, Warszawa 2018.

Rakowska-Trela A., Zasada demokratycznego państwa prawnego a zmiany w prawie wyborczym, „Studia Wyborcze” 2018, t. 25 s. 17-30.

Raźny P., Postępowanie sądowe $w$ sprawach zwiąanych z rozpowszechnianiem nieprawdy w kampanii wyborczej, „Studia Wyborcze” 2018, t. 26, s. 25-38.

Robak F., Charakterystyka systemu STV na przyktadzie prawa i praktyki wyborczej Irlandii, [w:] Aktualne problemy prawa wyborczego. Tom 2, red. E. Żelasko-Makowska, K. Mucha, B. Przywora, M. Wrzalik, Częstochowa 2018, s. 223-232.

Rozbicka P., Nawigatory wyborcze: czy możemy mówić o ich użyteczności w badaniach empirycznych?, „e-Politikon” 2018, nr 25, s. 203-222.

Rulka M., Australia: wyrok Sąu Najwyższego z 27 października 2017 r. w sprawie Re Canavan i inni, sygn. (2017) HCA 45, „Przegląd Sejmowy” 2018, nr 6, s. 253-264.

Rulka M., Opinia na temat zgodności projektu ustawy o zmianie niektórych ustaw w celu zwiększenia udziatu obywateli w procesie wybierania, funkcjonowania i kontrolowania niektórych organów publicznych (druk $n r$ 2001) - w części zmieniającej przepisy kodeksu wyborczego z europejskimi standardami wyborczymi, „Przegląd Sejmowy” 2018, nr 1, s. 165-179.

Rulka M., Procedura wyboru sołtysa w przypadku jednego kandydata. Glosa do wyroku WSA z dnia 22 marca 2018 r., III SA/Gd 97/18, „Orzecznictwo w Sprawach Samorządowych” 2018, nr 3, s. 119-125. 
Rulka M., Republika Poludniowej Afryki: wyrok Sadu Konstytucyjnego z 22 czerwca 2017 r. w sprawie Zjednoczony Ruch Demokratyczny przeciwko Przewodniczacemu Zgromadzenia Narodowego (dotyczacy możliwości ustanowienia tajnego głosowania w sprawie wniosku o wotum nieufności dla Prezydenta), sygn. CCT 89/17, „Przegląd Sejmowy” 2018, nr 2, s. 169-182.

Rulka M., Republika Włoska: wyrok Sadu Konstytucyjnego Republiki Włoskiej z 25 stycznia 2017 r. w sprawie italicum, sygn. 48b/2015, „Przegląd Sejmowy” 2018 , nr 1, s. 239-250.

Rulka M., Sformułowanie pytania $w$ referendum lokalnym $w$ świetle orzecznictwa, „Samorząd Terytorialny" 2018, nr 7-8, s. 118-130.

Rulka M., Stwierdzenie wygaśnięcia mandatu radnego z powodu niezamieszkiwania $w$ gminie prawowanego mandatu. Glosa do wyroku NSA z dnia 4 lipca 2017 r., II OSK 862/17, „Orzecznictwo w Sprawach Samorządowych” 2018, nr 1, s. 117-125.

Rulka M., Wróblewski B., Rozwiąania kodeksu wyborczego wpływające na zaufanie wyborców do procedury wyborczej. Uwagi de lege ferenda, „Przegląd Sejmowy” 2018, nr 2, s. 49-70.

Rytel-Warzocha A., Constitutional Referendum in Poland in the Light of Constitutional Regulation and Controversy Arising from Constitutional Practice, „Gdańskie Studia Prawnicze” 2018, t. XL, s. 289-301.

Rytel-Warzocha A., Szmyt A., Electoral Issues as the Subject of Petitions Submitted to the Sejm of the Republic of Poland of the Eight Term, „Polish Political Science Yearbook” 2018, vol. 47 (3), s. 467-475.

Sawa-Czajka E., Polska scena polityczna 1989-2018, Warszawa 2018.

Sawicz A., Wybory w cieniu pomarańczowej rewolucji, „Nowa Polityka Wschodnia” 2018, nr 4 (19), s. 39-76.

Schmidt A., Challenges of the Illiberal Democracy in Hungary. Some Aspects to the 2018 Elections, „Polish Political Science Review” 2018, vol. 6 (2) s.70-90.

Siedziako M., Bez wyboru: głosowania do Sejmu PRL (1952-1989), Warszawa 2018.

Sieklucki D., Konstytucja RP a ewolucja systemu wyborczego do Sejmu, „Horyzonty Polityki” 2018, vol. 9 (26), s. 77-91.

Sieklucki D., Pozycja partii postpezetpeerowskiej lewicy na polskiej scenie politycznej w perspektywie wyborów prezydenckich i parlamentarnych 2015 r., [w:] Geografia wyborcza Polski: interpretacje postaw i zachowań obywateli, red. T. Koziełło, D. Szczepański, Rzeszów 2018, s. 221-235.

Sieklucki D., Wybory 2015 roku w Polsce - analiza z perspektywy ewolucji systemu partyjnego, „Athenaeum. Polskie Studia Politologiczne” 2018, vol. 57, s. 20-34.

Skiba A., Obecność kobiet w systemach wyborczych w Europie, „Cywilizacja i Polityka” 2018, nr 16, s. 316-339.

Składowska J., Sposoby obejścia konstytucyjnego zakazu reelekcji - kazus Nikaragui, „Wrocławskie Studia Politologiczne" 2018, nr 24, s. 33-45.

Składowski K., Zasady prawa wyborczego w pierwszej ordynacji wyborczej w okresie II Rzeczypospolitej, [w:] Niepodległa. Rozważania prawno-ustrojowe w 100. rocznice odrodzenia suwerennego państwa polskiego, red. A. Domańska, A. Michalak, Łódź 2018, s. 151-161.

Skorupska M., Nieważne głosy $w$ wyborach parlamentarnych $w$ Polsce $w$ latach 2001-2015 z perspektywy badań geograficzno- politycznych, [w:] Geografia wyborcza Polski: interpretacje postaw $i$ zachowań obywateli, red. T. Koziełło, D. Szczepański, Rzeszów 2018, s. $113-130$.

Skotnicki K., Instytucja i-votingu w wybranych krajach, „Zeszyty Prawnicze BAS” 2018, nr 1, s. 71-85.

Skotnicki K., Kilka słów o i-votingu, [w:] Dookoła Wojtek.. Księga pamiątkowa poświęcona Doktorowi Arturowi Wojciechowi Preisnerowi, red. R. Balicki, M. Jabłoński, Wrocław 2018, s. 447-453. 
Skotnicki K., Możliwości kandydowania i sprawowania po wygranych wyborach funkcji wójta (burmistrza, prezydenta miasta) przez osobę skazana prawomocnym wyrokiem sadu za ścigane z oskarżenia publicznego przestępstwo popelnione z winy umyślnej na inna karę niż pozbawienie wolności, [w:] Potentia non est nisi da bonum: księga jubileuszowa dedykowana profesorowi Zbigniewowi Witkowskiemu, red. A. Bień-Kacała, A. Kustra-Rogatka, M. Serowaniec, Torun 2018, s. 709-718.

Skotnicki K., Udziat $w$ wyborach i referendach osób gluchych i niedostyszących, „Gdańskie Studia Prawnicze" 2018, t. XL, s. 315-321.

Skotnicki K., W sprawie dopuszczalności zakazu reelekcji wójta (burmistrza, prezydenta miasta) po piastowaniu urzędu przez dwie kadencje, „Wrocławskie Studia Politologiczne 2018, nr 24, s. 7-17.

Skrabacz E., Horoś B"., Ramowanie bezpieczeństwa $w$ debatach telewizyjnych w kampaniach wyborczych: samorzadowej (2014) i parlamentarnej (2015), „Chorzowskie Studia Polityczne" 2018, nr 15, s. 97-115.

Skrzypiński D., Wymiar finansowy alternacji $w$ wyborach samorzadowych $w 2014$ roku, „e-Politikon” 2018, nr 26, s. 165-182.

Sokala A., Kilka uwag do projektu zmian w kodeksie wyborczym z listopada 2017 r., „Gdańskie Studia Prawnicze" 2018, t. XL, s. 323-333.

Sokala A., Zmiany w systemie polskiej administracji wyborczej, „Studia Wyborcze” 2018, t. 25, s. $45-56$.

Stępień-Załucka B., Rola środków nowoczesnej komunikacji w wyborach, [w:] Geografia wyborcza Polski: interpretacje postaw i zachowań obywateli, red. T. Koziełł, D. Szczepański, Rzeszów 2018, s. 314-329.

Stępień-Załucka B., Zaufanie społeczne jako element e-votingu, [w:] Nowe wyzwania i rozwiazania w polskim systemie ochrony praw człowieka. Tom 4, red. J. Jaskiernia, K. Spryszak, Toruń 2018, s. 115-125.

Szalkiewicz W. K., Widoczność medialna a wynik wyborczy, „e-Politikon” 2018, nr 26, s. 65-79.

Szczepański D., Agitacja wyborcza na terenach kościelnych a postawy respondentów $w$ elekcjach wyborczych w Polsce w 2015 r., [w:] Geografia wyborcza Polski: interpretacje postaw i zachowań obywateli, red. T. Koziełło, D. Szczepański, Rzeszów 2018, s. 169-179.

Szukalski J., Ochrona praw człowieka w systemie instytucjonalnym OBWE, [w:] Nowe wyzwania i rozwiazania w europejskim systemie ochrony praw człowieka. Tom 3, red. J. Jaskiernia, K. Spryszak, Toruń 2018, s. 458-468.

Szwed M., Pozbawienie czynnego prawa wyborczego osób ubezwłasnowolnionych $w$ wyborach do Parlamentu Europejskiego w świetle Karty Praw Podstawowych UE, „Europejski Przegląd Sądowy” 2018, nr 12, s. 24-28.

Szymańska A., Wybory samorządowe 2014 w Małopolsce - stanowisko kandydatów na urząd prezydenta Krakowa oraz komitetów wyborczych $w$ wybranych kwestiach politycznych $i$ kanaty dystrybucji informacji wyborczej, [w:] Komunikowanie lokalno-regionalne w dobie spoleczeństwa medialnego. Tom 2, Aspekty polityczne, społeczne i technologiczne, red. M. Mazur, M. Kornacka-Grzonka, Katowice 2018, s. 81-94.

Szymański A., Beyond Vote Rigging: Common Patterns in Electoral Malpractices in DeDemocratizing Regimes, „Polish Political Science Yearbook” 2018, vol. 47 (4), s. 593-617.

Szymański P., Występowanie zjawiska koabitacji w miastach województwa zachodniopomorskiego, „Acta Politica Polonica” 2018, nr 1, s. 89-100.

Szyszlak E., Imigracja i imigranci w kampaniach wyborczych w Republice Czeskiej w 2017 i 2018 r., „Studia Europejskie” 2018, nr 2, s. 133-150.

Śladkowski M., Status prawny komisarza wyborczego, [w:] Geografia wyborcza Polski: interpretacje postaw i zachowań obywateli, red. T. Koziełło, D. Szczepański, Rzeszów 2018, s. $15-26$. 
Śladkowski M., Ważność wyborów samorzadowych w świetle Konstytucji RP, [w:] Aktualne problemy prawa wyborczego. Tom 2, red. E. Żelasko-Makowska, K. Mucha, B. Przywora, M. Wrzalik, Częstochowa 2018, s. 243-253.

Tokaj B., Istotne zmiany w kodeksie wyborczym, [w:] Konsekwencje rewolucji w prawie wyborczym, czyli jak postawić krzyżyk $i$ dlaczego w kratce, red. W. Hermeliński, B. Tokaj, A. Godzwon, A. Adamiec, Warszawa 2018, s. 193-206.

Tokaj B., Organy wyborcze wczoraj i dziś, [w:] Konsekwencje rewolucji w prawie wyborczym, czyli jak postawić krzyżyk i dlaczego w kratce, red. W. Hermeliński, B. Tokaj, A. Godzwon, A. Adamiec, Warszawa 2018, s. 69-83.

Tomaszewski N., Do the Celebrity Politics Really Matter for Hispanic Voters Today? The Comparison of Barack Obama's and Donald Trump's Presidential Campaigns, „Athenaeum. Polish Political Science Studies" 2018, vol. 59, s. 158-177.

Tomczak Ł., Partie i ugrupowania polityczne w wyborach do Sejmiku Województwa Zachodniopomorskiego, [w:] Geografia wyborcza Polski: interpretacje postaw i zachowań obywateli, red. T. Koziełło, D. Szczepański, Rzeszów 2018, s. 236-248.

Trubalski A., Opinia $w$ sprawie głosowania korespondencyjnego jako jednej z alternatywnych procedur wyborczych w wybranych państwach, „Przegląd Sejmowy” 2018, nr 1, s. 180-193.

Turska-Kawa A., Determinanty chwiejności wyborczej na poziomie lokalnym, „Athenaeum. Polskie Studia Politologiczne" 2018, vol. 58, s. 100-113.

Tybuchowska-Hartlińska K., Wybory w przestrzeni miejskiej - elekcje prezydentów miast w Polsce (2002-2014), [w:] Oblicza demokracji lokalnej. Wyzwania dla rozwoju miast, red. M. Obrębska, Sosnowiec 2018, s. 113-132.

Tyrała M., Wplyw postulatów programowych na sukces wyborczy - na przyktadzie partii: PiS, PO, ZL w wyborach parlamentarnych w Polsce w 2015 roku, „Środkowoeuropejskie Studia Polityczne" 2018, nr 1, s. 61-78.

Uliasz J., Regulacje krajowego prawa wyborczego a wzmacnianie zjawiska celebrytyzacji i tabloidyzacji kampanii wyborczych, [w:] Geografia wyborcza Polski: interpretacje postaw i zachowań obywateli, red. T. Koziełło, D. Szczepański, Rzeszów 2018, s. 27-37.

Urbaniak K., Wybory jako demokratyczny sposób kreowania organów władzy publicznej a dobro wspólne, „Ruch Prawniczy, Ekonomiczny i Socjologiczny” 2018, vol. 80 (1), s. $151-167$.

Urbaniak K., Zasada proporcjonalności w samorządowym prawie wyborczym, „Przegląd Prawa Konstytucyjnego" 2018, nr 4, s. 37-56.

Uwarunkowania demokracji bezpośredniej we wspótczesnej Europie, red. M. Musiał-Karg, A. Stelmach, Poznań 2018.

Uziębło P., Institutions of direct democracy, [w:] Polish political system An introduction, ed. J. Szymanek, Warszawa 2018, s. 239-255.

Uziębło P., Kilka uwag o rejestracji kandydatów oraz kampanii wyborczej w wyborach prezydenta Republiki Czeskiej, „Acta Universitatis Lodziensis. Folia Iuridica”, vol. 84, 2018, s. 85-97.

Uziębło P., My Naród, czyli o udziale suwerena w procedurze zmiany Konstytucji Rzeczypospolitej Polskiej, [w:] Aktualne problemy prawa Polski i Ukrainy, red. A. Szmyt, J.Boszycki, J. Stelina, W. Mikołajowicz Iwanow, Gdańsk 2018, s. 27-36.

Uziębło P., O możliwości połaczenia głosowania $w$ wyborach samorządowych $i w$ referendum ogólnokrajowym, [w:] Aktualne problemy prawa wyborczego. Tom 2, red. E. Żelasko-Makowska, K. Mucha, B. Przywora, M. Wrzalik, Częstochowa 2018, s. 255-263.

Uziębło P., O możliwości wprowadzenia rozwiazań włoskiego systemu wyborczego do prawa polskiego, [w:] Potentia non est nisi da bonum: ksiega jubileuszowa dedykowana profesorowi Zbigniewowi Witkowskiemu, red. A. Bien-Kacała, A. Kustra-Rogatka, M. Serowaniec, Toruń 2018, s. 799-811. 
Wałdoch M., Wplyw dyskursu o polityce imigracyjnej na wyniki wyborów parlamentarnych 2017 roku w Nowej Zelandii, „Prawo i Polityka” 2018, nr 8, s. 92-115.

Wasil J., Sidor M., Kuć-Czajkowska K. A., Consequences of the Electoral System in Polish Municipalities - Pathologies and Abuses, „Polish Political Science Yearbook” 2018, vol. 47 (3), s. 477-490.

Wincławska M., Pacześniak A., Members of Polish Political Parties in the Process of InterElectoral Campaigning, „Polish Political Science Yearbook” 2018, vol. 47 (4), s. 652-662.

Wiśniewski R., Polacy za granica - wyniki głosowania, [w]: Atlas wyborczy Polski, red. M. Kowalski, P. Śleszyński, Warszawa 2018, s. 323-336.

Witkowski J., "Latarnik Wyborczy", „e-Politikon” 2018, nr 25, s. 14-53.

Wojciechowska J., Election Petitions in Poland: The Efficiency Analysis of the Institution, „Polish Political Science Yearbook” 2018, vol. 47 (3), s. 491-502.

Wojciechowski J., Problem realizacji wymogu zebrania odpowiedniej liczby podpisów pod inicjatywa referendalna przez mieszkańców samorządu terytorialnego $w$ świetle orzecznictwa sqdów administracyjnych, [w:] Aktualna problematyka ustrojowa samorzadu terytorialnego w świetle orzecznictwa sadowego, red. T. Brzezicki, J. Wantoch-Rekowski, s. 69-90.

Wojnicki J., Instytucja referendum w systemach politycznych państw Europy Środkowej $i$ Wschodniej, [w:] Uwarunkowania demokracji bezpośredniej we wspótczesnej Europie, red. M. Musiał-Karg, A. Stelmach, Poznań 2018, s. 65-78.

Wojtasik W., Porażki partii politycznych w perspektywie zmian $w$ ustawodawstwie wyborczym, [w:] Anatomia porażki wyborczej, red. A. Pacześniak, Warszawa 2018, s. 21-38.

Wojtasik W., Wybory jako mechanizm demokratycznej zmiany, [w:] Demokracja, teoria prawa, sadownictwo konstytucyjne : ksiegga jubileuszowa dedykowana profesorowi zw. nauk prawnych Adamowi Jamrozowi z okazji pięćdziesięciolecia pracy zawodowej, red. M. Aleksandrowicza, M. Andruszkiewicz, A. Breczko, S. Oliwniaka, Białystok 2018, s. 179-188.

Woźnicki M., Rola komisarza wyborczego w procedurze podziału gmin na okręgi wyborcze $w$ wyborach do rad gmin w świetle Kodeksu wyborczego, „Przegląd Prawa Konstytucyjnego" 2018, nr 4, s. 121-143.

Wróbel J., Procedura protestu wyborczego przeciwko ważności wyborów do Sejmu i Senatu na tle orzecznictwa Sadu Najwyższego, [w:] Aktualne problemy prawa wyborczego. Tom 2, red. E. Żelasko-Makowska, K. Mucha, B. Przywora, M. Wrzalik, Częstochowa 2018, s. $265-273$.

Wybory 2015: partie $i$ ich programy, red. I. Słodkowska, ze wstępem M. Kotnarowskiego i R. Markowskiego, Warszawa 2018.

Wybory prezydenckie 2015: programy kandydatów, red. I. Słodkowska, ze wstępem A. Paczkowskiego, Warszawa 2018.

Zawadzka K., Działacze środowiska LGBT na polskiej scenie politycznej, [w:] Geografia wyborcza Polski: interpretacje postaw i zachowań obywateli, red. T. Koziełł, D. Szczepański, Rzeszów 2018, s. 180-192.

Zbieranek J., Głosowanie przez internet (i-voting) w wybranych państwach, „Zeszyty Prawnicze BAS" 2018, nr 1, s. 9-45.

Zbieranek J., Zmiany w kodeksie wyborczym w 2018 r.: wybrane zagadnienia, [w:] Aktualne problemy prawa wyborczego. Tom 2, red. E. Żelasko-Makowska, K. Mucha, B. Przywora, M. Wrzalik, Częstochowa 2018, s. 41-61.

Zięba-Załucka H., Media a demokracja w Polsce, „Przegląd Prawa Konstytucyjnego” 2018, nr 3, s. 59-76.

Ziętara W., Instytucja referendum w podmiotach Federacji Rosyjskiej : wymiar prawny i praktyczny, [w:] Uwarunkowania demokracji bezpośredniej we wspótczesnej Europie, red. M. Musiał-Karg, A. Stelmach, Poznań 2018, s. 91-107. 
Ziobro A., Wolność prasy a ochrona prywatności polityków w kampanii wyborczej, [w:] Geografia wyborcza Polski: interpretacje postaw i zachowań obywateli, red. T. Koziełł, D. Szczepański, Rzeszów 2018, s. 38-49.

Zoll A., Przedmowa, [w:] Konsekwencje rewolucji w prawie wyborczym, czyli jak postawić krzyżyk $i$ dlaczego w kratce, red. W. Hermeliński, B. Tokaj, A. Godzwon, A. Adamiec, Warszawa 2018, s. V-VIII.

Zubik M., Między profesjonalizmem a głosowaniem większości $w$ demokratycznym państwie prawa, „Zeszyty Naukowe Sądownictwa Administracyjnego” 2018, nr 5, s. 65-74.

Żelasko-Makowska E., Zapis dyskusji z panelu eksperckiego 'Aktualne problemy prawa wyborczego', [w:] Aktualne problemy prawa wyborczego. Tom 2, red. E. Żelasko-Makowska, K. Mucha, B. Przywora, M. Wrzalik, Częstochowa 2018, s. 9-37.

Струтинська Т. Конститучійні засади проведення місиевих виборів в Украӥні та крайнах Вишеградської Групи, [w:] Samorzad terytorialny w konstytucjach wybranych państw Europy Środkowo-Wschodniej. Zarys problematyki, red. I. Lasek-Surowiec, Chełm 2018, s. $103-112$. 